\title{
KNOWLEDGE TO RECOVER THE BUILT HERITAGE: CASE STUDY OF "SAN ROCCO" CHURCH IN MATERA, ITALY
}

\author{
ANTONELLO PAGLIUCA, MICHELE D’AMATO \& PIER PASQUALE TRAUSI \\ University of Basilicata, Italy
}

\begin{abstract}
The process of recovery, restoration and valorization of the built heritage is articulated, both for the complexity of historical architecture and the lack of adequate intervention tools. Each monument is an expression of the territory where it was built. Therefore, it's necessary to plan the restoration of built heritage as a system in which technical and cultural variables create a balance between decisions and processes of conservation and transformation. In this context, the technicians must activate a series of procedures to safeguard the monuments starting from the recovery of the values preserving its future memory. This methodological approach has been tested in the recovery project of the ancient masonry church of "San Rocco" in Matera (Italy). It is dated from the 14th century, and it also has a great importance for the hosting of cultural and social activities within the Matera Cultural Capital of Europe 2019 Program. The preliminary phase of data acquisition, the direct survey of the degradation characteristics and the historical-constructive research is shown in this paper. Then, a critical analysis of the survey is performed together with a preliminary analysis of its seismic performance. The numerical analyses have been conducted with the macro-elements approach, where the most probably failure mechanisms of the church architectural parts are taken into considerations.

Keywords: knowledge, constructive techniques, recovery intervention, seismic assessment.
\end{abstract}

\section{INTRODUCTION}

The historical architectures, through their artistic, cultural and architectural declinations, represent a heritage strictly linked to the identity of the place where they are built. Usually, these architectures (especially the religious ones) represent the most important buildings for a communities and the core of the religious part of society, too. The churches, in fact, as a part of consolidated fabric of the historic city, due to their uniqueness, are a morphological and typological sample of the continuous change, related to the historical and social conditions and to the new needs of the community.

These architectures, constructed by local builders, represent a complex historical and architectural heritage to be protected, since they are bearers of constructive knowledge, and of artistic and architectural peculiarities [1]. This will allow of highlighting the history and values of these monuments, which are an expression of culture and of society development in its urban context [2].

Hence, the difficulties of the conservation and recovery interventions of these architectures appear immediately evident; the solution could be the experimentation of a methodology starting from the in-depth knowledge of its typological, architectural, constructive and material characteristics for arriving at the definition of recovery intervention [3]. In fact, it is from the material and constructive analysis that it is possible to read the tradition characteristics described by their materials, and the relationships among places, men and architectures. The knowledge of these elements becomes the fundamental point for a correct approach aimed at their recovery, through a project becoming a "mediation" for transmitting their history and values to future generations, as well. 
Therefore the "integrated" preservation of material and constructive identity becomes a dynamic action to build the future, in the complex architectural and social system that finds its essential identity in the cultural values of these architectures.

In this paper, knowledge, analysis and project are used to define the recovery intervention of one of the most important architectural and religious sites in Matera, the "San Rocco" church. The church is located in the heart of the historic city, in a strongly typified architectural and urban context, representing a very important building for the cultural history of the city.

\section{CASE STUDY: "SAN ROCCO" CHURCH IN MATERA}

The church of "San Rocco" is located among the historic buildings of the city center in Matera, just outside the ancient walls of the "civita" (the highest part of the city), between the "Sasso Barisano" and the "Largo di San Biagio", next to another church called "San Giovanni Battista" (Figs 1 and 2). The church origins are date back to the 14th century, when the city was marked by a virulent pestilence that made necessary to build a hospital to receive pilgrims and the sick. With a Papal Bull of 1348 [1], it was decreed the construction of the "San Rocco" hospital next to a small votive temple. It would have kept the image of "San Rocco" on the main altar.

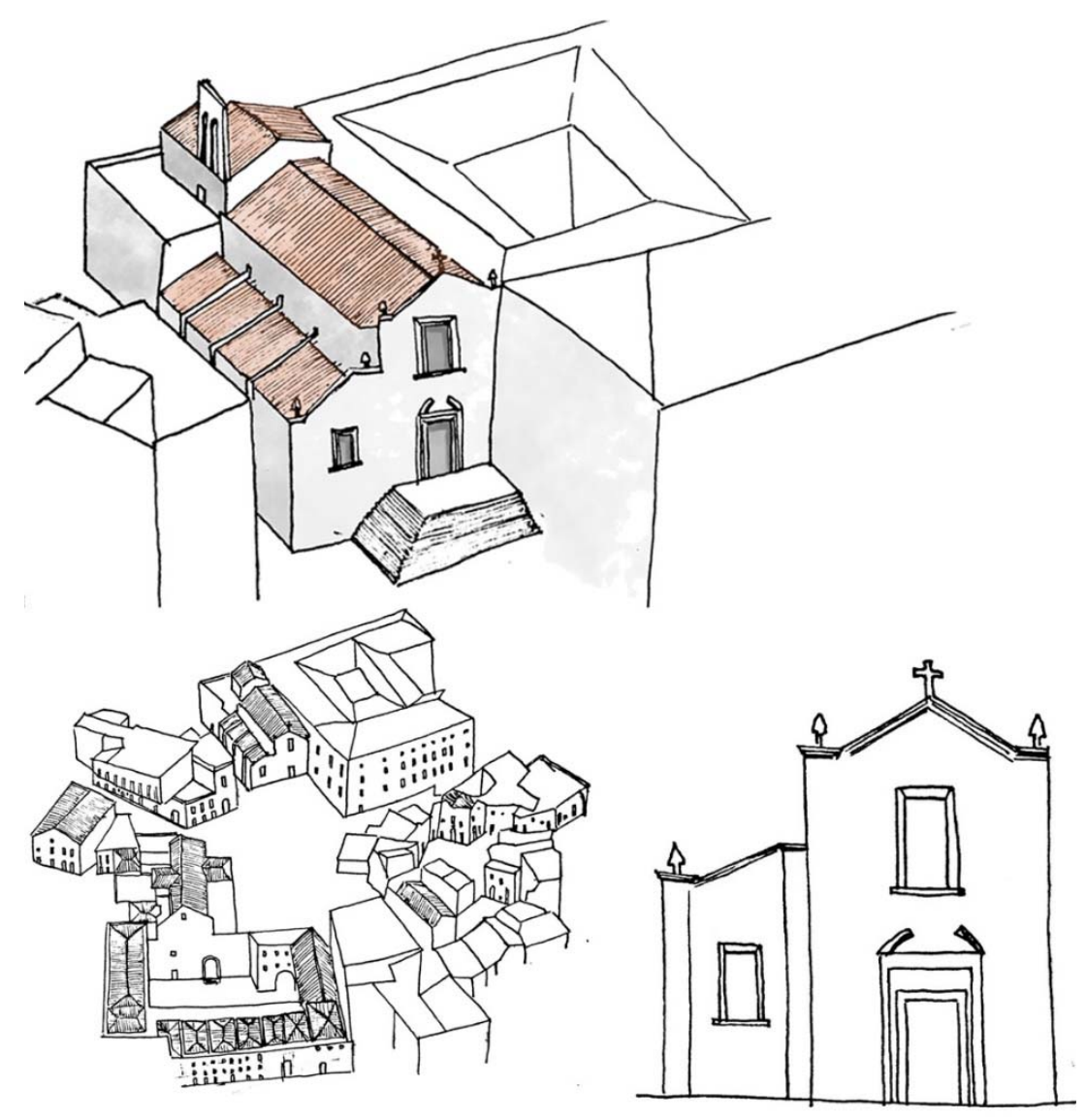

Figure 1: "San Rocco" church in the urban area of city center. 


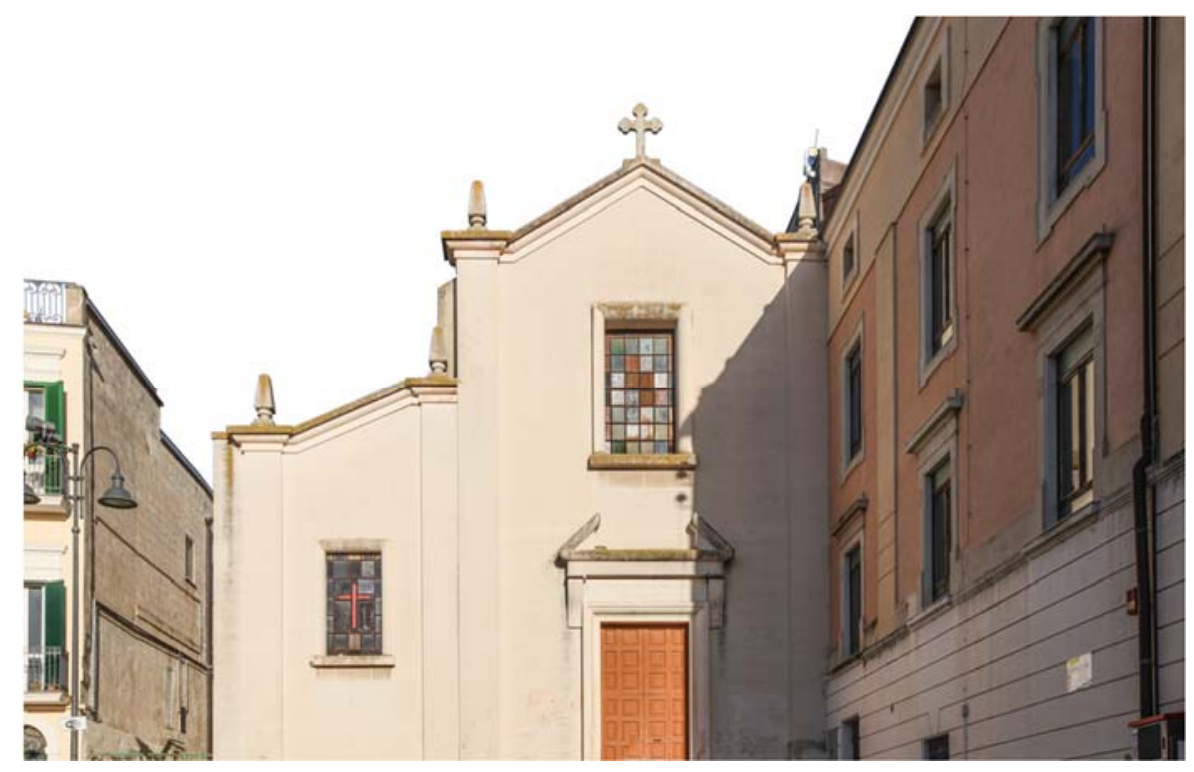

Figure 2: "San Rocco" church.

The church of "San Rocco" was in a bad state throughout the 15th century until the year 1604, when it was passed under the property of the Reformed Franciscan Community. The friars, custodians of the religious community and of the church, used the church for the ceremonies in honor of the cult of "San Rocco" until the precarious static conditions of the building required demolition and reconstruction in the same area. In about 1700, the friars commissioned to a designer (whose name is unknown) to design a religious building similar to the others in the province. Therefore, it was built a church on a square plan, developed in two aisles. The main nave was defined by a system of four rectangular areas with a sail vaults and opens, on the bottom, onto a small presbytery (Fig. 3). This presbyterial area, on the other hand, was separated from the main nave by a triumphal arch, and concluded by an apse containing the choir on two levels. It is particularly interesting, moreover, the importance of this church from a religious and artistic point of view. In fact, it became the custody of some important 18th century works commissioned to important artists of the period by the "San Rocco" friars community. Among them there were some paintings by Giacomo da San Vito, an "Immacolata" and "San Pietro d'Alcantara" and a canvas by Francesco da Martina depicting the "Annunciazione e il Perdono di Assisi" [4].

Following the social and historical evolution of the city, with the suppression of the religious orders ordered by the government in the same year and the building ownership transferring to the Municipality, the Hospital of "San Rocco" was again used as hospital, and subjected to remarkable transformations and readjustments. They ended in 1936 with the enlargement and the raising of the building. In the same way, the façade of the church of "San Rocco" was affected by these changes which, first of all, had to renounce to the bell gable having three arches. Subsequently, the ancient facade was replaced with one having a Modern Style. The new façade was in line with the architectural trends of the period, defined by a compositional clarity and a clear linearity of the openings, mediated by the use of moldings and materials recalling a Rationalist Style, despite of the traditional nature of the context. 


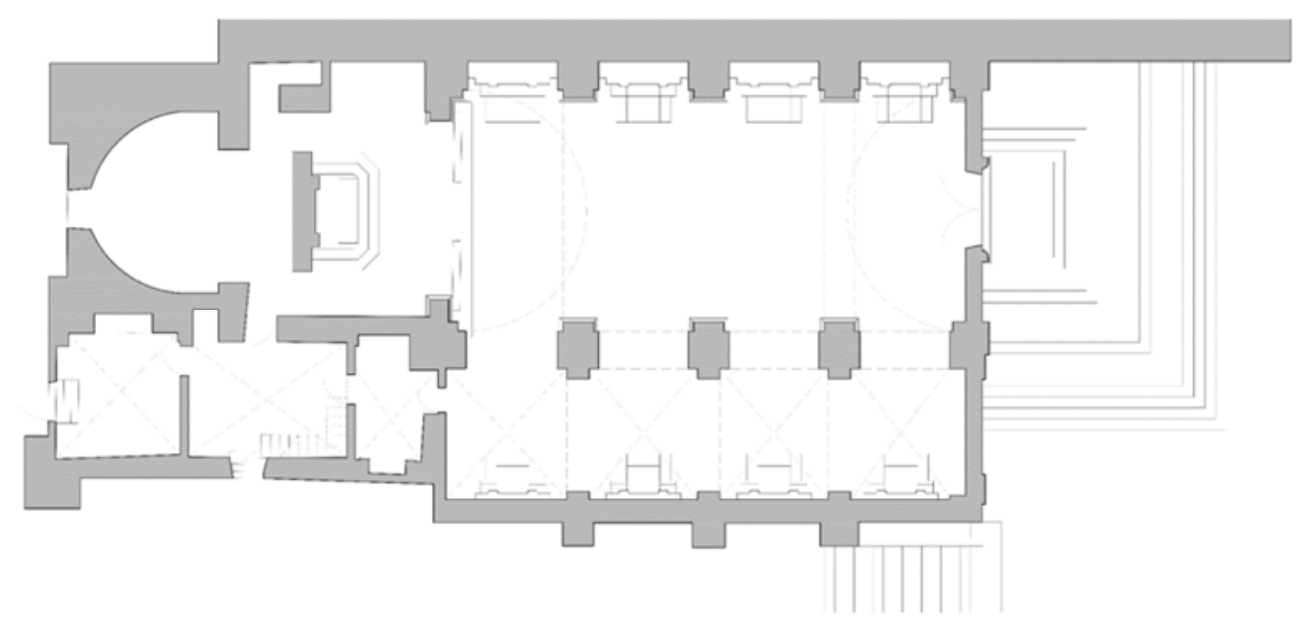

Figure 3: Plan of the church of San Rocco in Matera.

\section{THE STONE AS "REFLECTION" OF LOCAL CONSTRUCTIVE TECHNIQUES}

The church of "San Rocco" has a masonry structure made of the local limestone called "tufo", applied in squared blocks of different sizes for vertical walls and vaulted systems (Fig. 4). The walls thickness of the church results between about $50 \mathrm{~cm}$ and $75 \mathrm{~cm}$, consisting of a sack wall defined by two "skins", where blocks have dimensions of $20 \times 25 \times 50 \mathrm{~cm}$, and filled in the middle with flakes of stone and mortar (forming a compact low-strength conglomerate). According to the construction rules of the past, the so-composed two-leaf masonry is also transversely connected by blocks (defined "diatones" with a longitudinal dimension between 25 and $27 \mathrm{~cm}$ ), ensuring a better monolithic behavior to the resulting wall. Thin mortar joints, with a thickness not greater than $0.5 \mathrm{~cm}$, are present within the masonry composed by tufo powder used as an inert and mixed with lime. The arches and vaults, covering the main nave and the presbyteral area are filled in the abutments with waste dry materials. The roof is characterized by a traditional wooden truss system, formed by two struts, a monk, two lightning bolts and a chain, joined by metal elements mechanically anchored to the structural elements of the truss. The tegument, of typology called "coppo" in brick, constitutes the roof sealing layer, supported by a double warp of currents and wooden battens laid directly on the truss struts.

The analytical knowledge of the construction and technological system, as described above, constitutes the essential condition for carrying out a correct assessment of the building actual state. In addition, this approach allows to develop a recovery project, also suitable with the historical nature of the building and respectful of its peculiarities.

\section{SEISMIC VULNERABILITY ASSESSMENT}

In this study the macro-element approach is used for evaluating the seismic vulnerability assessment of the "San Rocco" church. According to this method the church structure is considered composed by different architectonic elements (such as the façade, the apse, the triumphal arch, etc.) that, under seismic lateral actions, behave independently of each other. This assumption derives from the damages observed during the recent Italian earthquakes, 

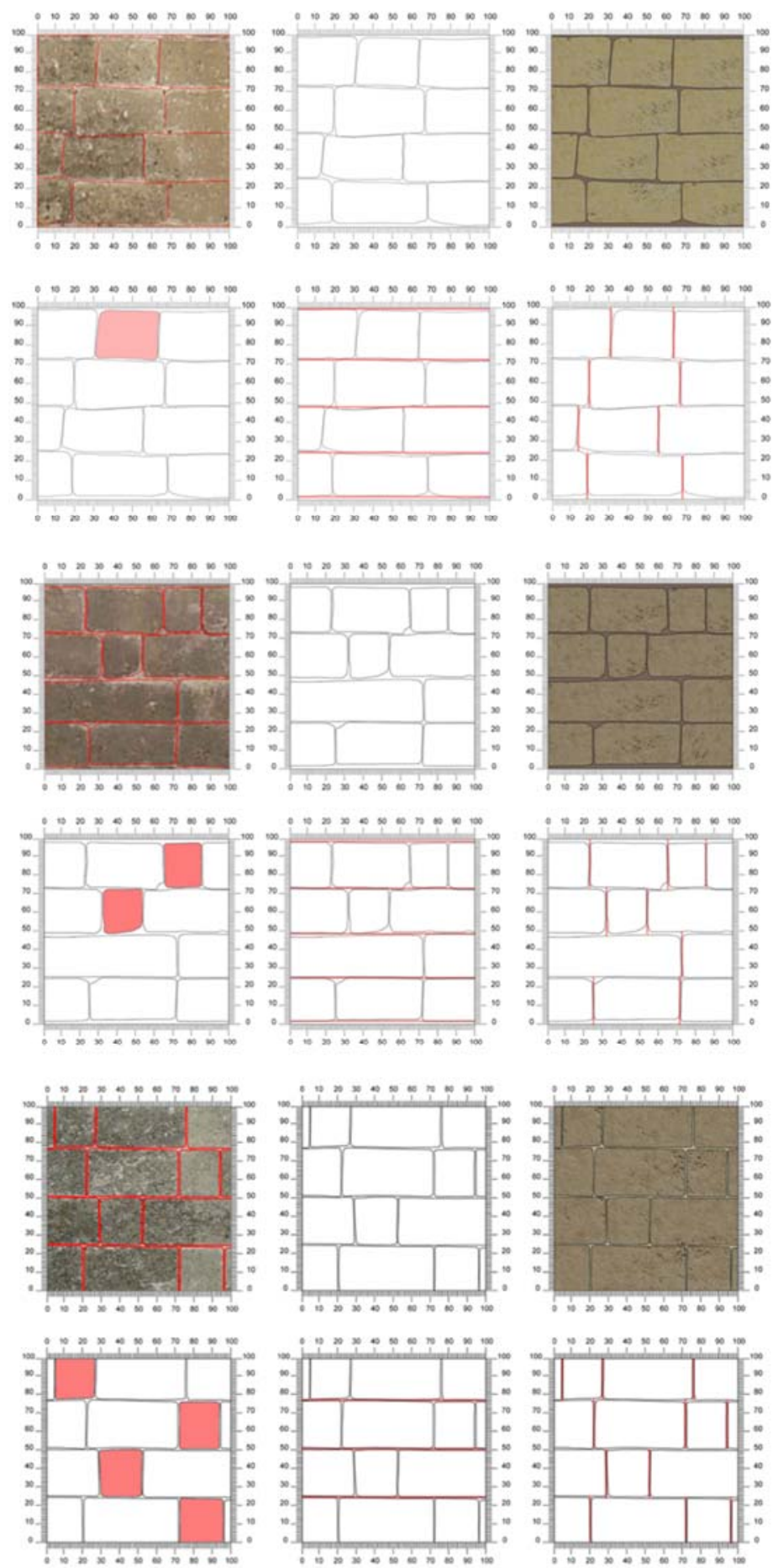

Figure 4: Analysis of masonry to define the constructive characteristics. 
where it was observed that masonry ancient churches suffered localized damage only in some architectural parts, named macro-elements [5]-[7]. It is evident that these macro-elements response mechanisms may arise if local desegregation is completely inhibited, and that they are heavily influenced by the construction details, such as the connections with other elements, presence of pushing elements that may facilitate their activation, previous interventions, etc. Discussions about these issues may be found in [8]-[13]. Recently, the recurrence character of the seismic damage has been confirmed also in the Mexican churches during the surveys conducted after the seismic sequence of September 2017 [14].

More in general, in the Italian Directive [15] three different valuation levels for seismic assessment of cultural heritage are indicated, having a decreasing approximation level:

- Level of Valuation 1 (LV1), for seismic assessment at a territorial scale. Applications may be found in [16], [17];

- Level of Valuation 2 (LV2), for local seismic assessment, by the means of the macroelements approach. Discussion about these aspects are reported in [16], [18];

- Level of Valuation 3 (LV3), suitable for local seismic assessment, by using also finite elements models. Applications may be found in [19].

As far as the LV2 approach is concerned, the Italian Directive indicates 28 different potential response mechanisms that may occur under a later seismic action. Among these, the ones considered in this work are detailed in the following. One may one that the mechanisms considered regards macro-elements that are ground-connected at the base.

- Main façade overturning. This mechanism is one of the most frequent, since it is highly vulnerable with respect to the lateral actions. It is activated by the formation of cylindrical hinges, horizontal or inclined, around which the rotation of the façade portions takes place. Very frequently the formation of the hinges occurs at the base of façade. This mechanism is facilitated by pushing elements, such as arch vaults or arches, or else by the absence of connection with lateral walls.

- Lateral wall overturning. This mechanism is also very frequent and is provoked, as for the main façade, by the formation of a cylindrical hinge at the base or at a certain height, facilitated by pushing elements.

- Nave transversal response. In this case, the mechanism regards the transversal response of the main aula including any lateral element, such as lateral naves/arches if present.

- Colonnade longitudinal response. This response mechanism is characterized by the activation of a global response of the colonnade delimiting the main aula.

The Italian Directive [15] permits of calculating the seismic vulnerability of the different macro-elements through the linear kinematic analysis based on the theorem of virtual works

$$
\alpha_{0}\left(\sum_{i=1}^{n} P_{i} \delta_{x, i}+\sum_{j=n+1}^{n+m} P_{j} \delta_{x, j}\right)-\sum_{i=1}^{n} P_{i} \delta_{y, i}-\sum_{h=1}^{o} F_{h} \delta_{h}=L_{f i},
$$

where the significance of the symbols may be found in [15], [16], [18]. Starting from the eqn (1) it is possible to calculate the activation multiplier $\alpha_{0}$ and, then, the corresponding seismic spectral acceleration $a_{0}{ }^{*}$ through the standard modal analysis principle

$$
a_{0}^{*}=\frac{\alpha_{0} \sum_{i=1}^{n+m} P_{i}}{M^{*} F C}=\frac{\alpha_{0} g}{e^{*} F C} .
$$

As far as the life-safety limit state (LSLS) verifications are concerned, they are conducted by comparing the response mechanism capacity in terms of spectral acceleration $a_{0}{ }^{*}$ with the seismic demand depending on the expected seismic acceleration, on the possible stratigraphic amplification $S$, and on the dissipative capacity measured through the behavior factor $q$ 


$$
a_{0}^{*}>\frac{a_{g}\left(P_{V R}\right) \cdot S}{q},
$$

where $S$ has been assumed equal to 1 (foundation on rock), $q$ equal to 2 as suggested by the Italian Design Code [20], while $a_{g}\left(P_{V R}\right)$ for LSLS results equal to $0.114 \mathrm{~g}$. The latter has been calculated starting from the site seismic hazard and, as indicated in [15], by assuming a reduced reference period $V_{R}$ of 30 years, given by a reduced nominal life $V_{N}$ of 20 years, and a coefficient of use $C_{U}$ of 1.5 due to the manufact importance. It should be remarked that in [15] it is permitted to reduce the nominal life for the cultural heritage, with respect to ordinary buildings. In this way it is allowed of reducing the seismic risk for the very frequent earthquakes by the means of light, reversible and economic interventions.

In Fig. 5 the macro-elements considered are reported, while in Table 1 the results obtained are summarized. In particular, in the Table 1 the acceleration actor $f_{a}$ is also reported, defined in general as

$$
f_{a, L S L S}=\frac{a_{L S L S}}{a_{g, L S L S}} .
$$

$f_{a}$ is defined as the ratio of the seismic capacity to the demand, where the seismic capacity is expressed through the spectral acceleration $a_{0}{ }^{*}$, while the seismic demand is measured

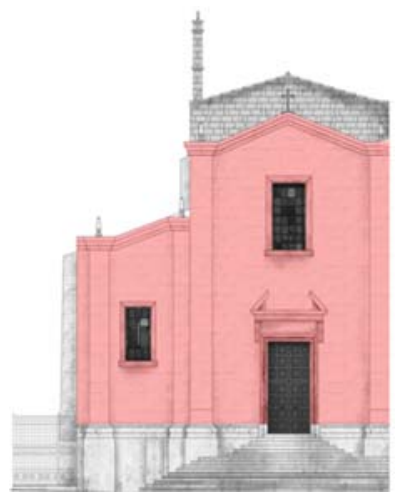

(a)

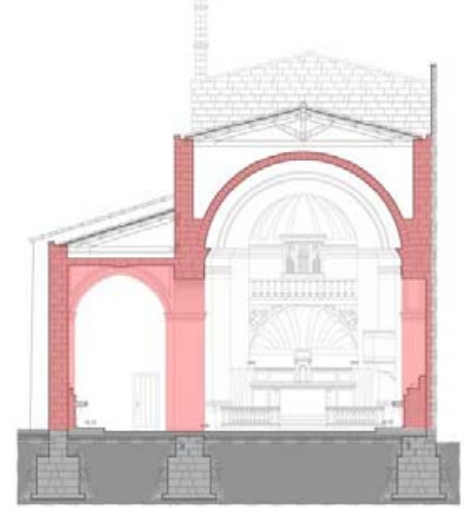

(c)

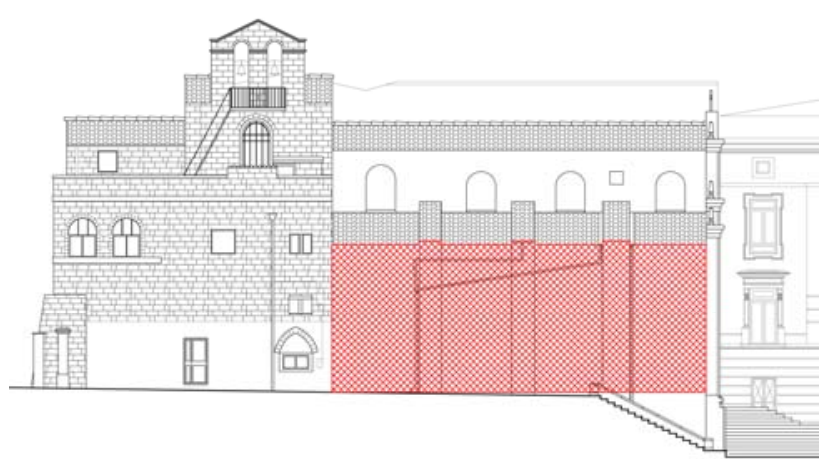

(b)

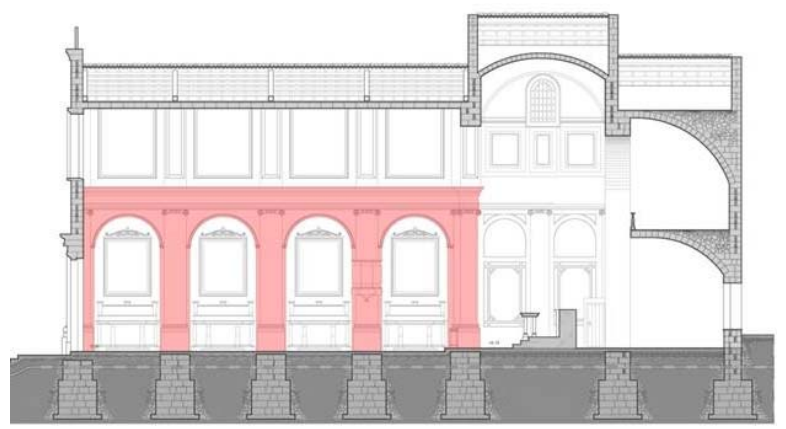

(d)

Figure 5: Macro-elements considered. (a) Main façade; (b) Lateral wall; (c) Nave transversal response; and (d) Longitudinal colonnade. 
Table 1: Seismic vulnerability of the considered macro-elements and acceleration factor $\mathrm{f}_{\mathrm{a}}$.

\begin{tabular}{|l|c|c|c|}
\hline & $\begin{array}{c}\text { Capacity } \\
\mathrm{a}_{0}{ }^{*}(\mathrm{~g})\end{array}$ & $\begin{array}{c}\text { Demand } \\
\mathrm{ag}_{\mathrm{g}} \mathrm{S} / \mathrm{q}\end{array}$ & $\mathrm{f}_{\mathrm{a}}$ \\
\hline (a) Main façade overturning & 0.050 & 0.057 & 0.877 \\
\hline (b) Lateral wall overturning & 0.161 & 0.057 & 2.824 \\
\hline (c) Nave transversal response & 0.108 & 0.057 & 1.894 \\
\hline (d) Colonnade longitudinal response & 0.106 & 0.057 & 1.860 \\
\hline
\end{tabular}

through the second term of the eqn (3). The acceleration factor is an index expressing the seismic performance in terms of lateral strength. If it results lower than unity, the structure or some its component does not satisfy the seismic protection level required for the considered limit state.

The numerical results reported in the Table 1 highlight that the most vulnerable mechanism, among the ones considered, is the main façade overturning, resulting an acceleration factor $f_{a}$ lower than 1 . As known, the vulnerability of this mechanism may be reduced by considering steel chains opposing to the out-of-plane overturning. While, as for the others mechanisms they result greater than 1 and, therefore, they won't be activated with respect to the expected seismic demand. It must be clarified that in this study some construction details have been neglected in calculating the activation multiplier of each mechanism. Consequently, the spectral accelerations $a_{0}{ }^{*}$ found underestimate the actual ones. This aspect is particularly important in the case of the façade overturning mechanism, where the actual connection grade with orthogonal would make the mechanism considered less vulnerable than the assumed one, where no lateral wall interaction has been taken into account. Appropriate in situ investigations would clarify this aspect reducing the approximation of the evaluation performed.

\section{CONCLUSIONS}

In this paper a preliminary seismic analysis of the "San Rocco" church has been illustrated. The study has highlighted the importance of the knowledge, analysis and project within a complete design framework aimed to the cultural heritage preservation. The preliminary seismic assessment carried out accordingly to the macro-element approach has demonstrated that, in the case study considered, the façade overturning is the most vulnerable response mechanism to be prevented with respect to the other ones. However, in situ investigations should be performed in order to realistically define the actual connection level between the façade and the lateral walls. The knowledge of these details will make the macro-element model closer to the actual conditions, providing a more realistic prediction of the seismic behavior.

In general, the knowledge of the construction details, will allow of conducting more refined analyses capable of dimensioning rational and non-invasive interventions, respecting the integrity of the cultural heritage and the principle of being reversible as more as possible.

\section{REFERENCES}

[1] Carbonara, G., Trattato di restauro architettonico, UTET: Torino, 2007.

[2] Esposito, D., Tecniche costruttive dell'edilizia storica. Conoscere per conservare, Viella, 2005.

[3] Picone, R., Il restauro e la questione dello "stile". Il secondo Ottocento nel mezzogiorno d'Italia, Arte'm, 2012. 
[4] Padula, M. \& Motta, C., Le chiese di San Giovanni e San Domenico, BMG: Matera, 1995.

[5] Doglioni, F., Moretti, A. \& Petrini, V., Churches and the Earthquake, LINT: Trieste, 1994.

[6] Lagomarsino, S. \& Podestà, A., Seismic vulnerability of ancient churches. Part 1: Damage assessment and emergency planning. Earthquake Spectra, 20(2), pp. 377394, 2004.

[7] Lagomarsino, S. \& Podestà, S., Seismic vulnerability of ancient churches. Part 2: statistical analysis of surveyed data and methods for risk analysis. Earthquake Spectra, 20(2), pp. 395-412, 2004.

[8] de Felice, G. \& Giannini, R., Out of plane seismic resistance of masonry walls. Journal of Earthquake Engineering, 5(2), pp. 253-271, 2001.

[9] D'Ayala, D. \& Speranza, E., Definition of collapse mechanisms and seismic vulnerability of historic masonry buildings. Earthquake Spectra, 18, pp. 479-509, 2003.

[10] Lagomarsino, S. \& Resemini, S., The assessment of damage limitation state in the seismic analysis of monumental buildings. Earthquake Spectra, 25(2), pp. 323-346, 2009.

[11] Lagomarsino, S., Damage assessment of churches after l'Aquila earthquake (2009). Bullettin of Earthquake Engineering, 10, pp. 73-92, 2012.

[12] D'Amato, M., Laterza, M. \& Casamassima, V.M., Seismic performance evaluation of a multi-span existing masonry arch bridge. Open Civil Engineering Journal, 11(11), pp. 1191-1207, 2017.

[13] Luchin, G., Ramos, L.F. \& D'Amato, M., Sonic tomography for masonry walls characterization. International Journal of Architectural Heritage, 2018.

[14] Fuentes, D.D., Baquedano Julià, P.A., D’Amato, M. \& Laterza, M., Preliminary seismic damage assessment of mexican churches after september 2017 earthquakes. International Journal of Architectural Heritage, 2019.

[15] G.U. n. 47. (February 26, 2011), Directive of the Prime Minister dated 09/02/2011. Assessment and mitigation of seismic risk of cultural heritage with refeence to the technical code for the design of construction, issued by D.M. 14/01/2008. (In Italian.)

[16] D'Amato, M., Laterza, M. \& Diaz, D., Simplified seismic analyses of ancient churches in Matera's landscape. International Journal of Architectural Heritage, 2018. DOI: $10.1080 / 15583058.2018 .1511000$.

[17] Fuentes, D.D., Laterza, M. \& D'Amato, M., Seismic vulnerability and risk assessment of historic constructions: The case of masonry and adobe churches in Italy and Chile. 11th International Conference on Structural Analysis of Historical Constructions, Cusco, Perù, 11-13 Sep. 2018, pp. 1127-1137, 2019.

[18] D'Amato, M., Gigliotti, R. \& Laguardia, R. Comparative seismic assessment of ancient masonry churches. Frontiers in Built Environment, 5(56), 2019.

DOI: 10.3389/fbuil.2019.00056.

[19] Ramírez, E., Lourenço, P.B. \& D’Amato, M., Seismic assessment of the Matera Cathedral. Proceedings of SAHC 2018, 11th International Conference on Structural Analysis of Historical Constructions, Cusco, Perù, 11-13 Sep. 2018, pp. 1346-1354, 2019.

[20] Ministerial Decree MD (17/01/2018), Aggiornamento delle Nuove Norme Tecniche per le Costruzioni di cui al D.M. 17 Gennaio 2018. S.O. n. 8 of the Official Gazette of the Italian Republic published on 20/02/2018, n. 42. (In Italian.) 